\title{
Constraints to the timing of India-Eurasia collision determined from the Indus Group: a reassessment
}

\author{
Alexandra L Henderson ${ }^{1 *}$, Yani Najman ${ }^{1}$, Randall R Parrish², Andrew Carter ${ }^{3}$, Marcelle Boudagher- \\ Fadel $^{3}$, Gavin Foster ${ }^{4}$, Eduardo Garzanti ${ }^{5}$ and Sergio Andò ${ }^{5}$
}

\author{
1 Department of Environmental Science, Lancaster University, Lancashire, UK \\ 2 NERC Isotope Geosciences Laboratory, British Geological Survey, Nottingham, UK \\ 3 Department of Earth Sciences, University College London, University of London, UK \\ ${ }_{4}$ Department of Earth Sciences, Wills Memorial Building, University of Bristol, UK \\ 5 Dipartimento di Scienze Geologiche e Geotecnologie, Universita Milano-Bicocca, Milano, ITALY \\ * For correspondence, email: a.henderson@lancaster.ac.uk
}

The Indus Group is a Tertiary aged sequence composed of marine and terrestrial sedimentary rocks which were deposited in an evolving late-forearc to intermontane basin setting during the initial phases of Indian-Asian continental collision (Brookfield and Andrews-Speed 1984, Van Haver 1984, Searle et al. 1990, Sinclair and Jaffey 2001, Clift et al. 2002). For this reason, the Indus Group provides the earliest record of erosion from the Himalayas. Clift et al. (2002) have constrained the age of collision by determining the lowermost stratigraphic point in the Indus Group that contains detritus from both Indian and Asian plates, and also by identifying where the Asian plate derived Indus Group unconformably overlies Indian plate margin sediments. The Chogdo Formation, dated by an overlying limestone at older than 54.9 Ma (O. Green, unpublished data cited in Sinclair and Jaffey 2001) is identified by Clift et al. (2001), to be the oldest unit of the Indus Group to contain detritus from both the Indian and Asian plates, and to stratigraphically overly Lamayuru Group Indian slope turbidites and Jurutze forearc basin rocks, thereby pinpointing the timing of continental collision to the Late Paleocene. However, despite its importance, these previous evaluations of the Indus Group have been hampered by poor stratigraphic knowledge and uncertain lateral correlations, largely due to the relatively complex deformation of the rocks and poor biostratigraphic control.

We use a combination of geological mapping, biostratigraphy, facies analysis, petrography, bulkrockgeochemistry, and isotopic characterisation of single detrital grains to 1) create an accurate and more widely representative stratigraphy for the Indus Group, 2) determine the nature of the contacts which separate the overlying Indus Group from underlying Indian and Asian Plate formations and 3) determine the provenance of the Group, in particular the stratigraphic level within the Indus Group at which both Indian and Asian plate detrital minerals occur together, in order to constrain the time of collision and discover which geological terranes where exhumed and actively eroded during the early stages of the Himalayan orogeny. Our Initial analyses indicate that the Chogdo Formation may not be as widely occurring as previous interpretations have led to believe; partly due to obscured tectonic contacts and problems with lateral correlations along strike. Therefore certain formations which are currently identified as belonging to the Chogdo Formation may well be younger (<48.6 Ma; Wu et al. 2007) Indus Group formations. Reassessment of constraints to the timing of IndiaAsia collision as determined from the Chogdo Formation is required.

References

Brookfield ME and CP Andrews-Speed. 1984. Sedimentology, petrography and tectonic significance of the shelf, flysch and molasse clastic deposits across the Indus suture zone, Ladakh, NW India. Sedimentary Geology 40: 249-286

Clift PD, N Shimizu, GD Layne and J Blusztajn. 2001. Tracing patterns of erosion and drainage in the Paleogene Himalaya through ion probe $\mathrm{Pb}$ isotope analysis of detrital K-feldspars in the Indus Molasse, India. Earth and Planetary Science Letters 188: 475-491

Clift PD, A Carter, M Krol and E Kirby. 2002 Constraints on IndiaEurasia collision in the Arabian sea region taken from the Indus Group, Ladakh Himalaya, India. In: Clift PD, D Kroon, C Geadicke and J Craig (eds), The Tectonic and Climatic Evolution of the Arabian Sea Region. Geological Society Special Publication 195: 97-116

Searle MP, KT Pickering and DJW Cooper. 1990. Restoration and evolution of the intermontane molasse basin, Ladakh Himalaya, India. Tectonophysics 174: 301-314

Sinclair HD, and N Jaffey. 2001. Sedimentology of the Indus Group, Ladakh, northern India; implications for the timing of the initiation of the palaeo-Indus River. Journal of the Geological Society of London 158: 151-162

Van Haver T. 1984. Etude stratigraphique, sedimentologique et structurale d'un bassin d'avant arc: Exemple du bassin de l'Indus, Ladakh, Himalaya [Ph.D dissertation]. Grenoble, France: Universite de Grenoble:204 p

Wu FU, PD Clift and JH Yang. 2007. Zircon Hf isotopic constraints on the sources of the Indus Molasse, Ladakh Himalaya, India. Tectonics 26: TC2014 